\title{
A Catalytic Mechanism for the Enzyme Benzylamine Oxidase from Pig Plasma
}

\author{
By C. E. TAYLOR, R. S. TAYLOR, C. RASMUSSEN and P. F. KNOWLES \\ Astbury Department of Biophysics, University of Leeds, Leeds LS2 9JT, U.K.
}

(Received 3 May 1972)

\begin{abstract}
Initial-velocity and product-inhibition studies on the enzyme benzylamine oxidase from pig plasma indicate that the order of substrate addition and product release is benzylamine on, ammonia off, oxygen on, hydrogen peroxide off, benzaldehyde off. Ammonia, but not benzaldehyde, is released under strictly anaerobic conditions which provides independent evidence for this order. Benzyl alcohol is a substrate for the enzyme. A chemical mechanism consistent with all the data is proposed.
\end{abstract}

A group of amine oxidases distinct from the flavincontaining mitochondrial amino acid oxidases (Meister \& Wellner, 1963) has been recognized during the past 20 years. Examples of this group have been found in mammals (Tabor et al., 1954; Blaschko et al., 1959; Yamada \& Yasunobu, 1962; Mondovi et al., 1964), plants (Mann, 1955, 1961) and microorganisms (Yamada et al., 1969). Although the substrate specificity of these enzymes differs, there is considerable evidence to suggest that they contain cupric copper (Buffoni \& Blaschko, 1964; Yamada et al., 1963; Mondovi et al., 1967; Buffoni et al., 1968) and either pyridoxal phosphate (Yamada \& Yasunobu, 1963; Blaschko \& Buffoni, 1966) or some carbonyl compound (Hill, 1967). One of the bettercharacterized enzymes in this group is the benzylamine oxidase (EC 1.4.3.4) from pig plasma (Buffoni \& Blaschko, 1964), which has been crystallized in homogeneous form and shown to contain 3-4mol of pyridoxal phosphate (Blaschko \& Buffoni, 1965) and approximately three atoms of cupric copper (Buffoni \& Blaschko, 1964; Buffoni et al., 1968)/mol of enzyme. Little is known about the catalytic mechanism for this enzyme. The present paper is mainly concerned with the application of steady-statekinetic methods to study the order of substrate addition to and product leaving from the enzyme.

\section{Experimental}

\section{Materials}

Sephadex G-25 and DEAE-Sephadex A-50 were obtained from Pharmacia, Uppsala, Sweden; DEAEcellulose DE-32 (microgranular), Aristar-grade $\left(\mathrm{NH}_{4}\right)_{2} \mathrm{SO}_{4}$ (used in the enzyme purification beyond stage III) and general chemicals (all AnalaR grade) were from British Drug Houses Ltd., Poole, Dorset, U.K. Columns (1.0- and 1.5-litre fixed vol.) were purchased from Wright Scientific, London, N.W.6,
U.K. Glass chromatography columns (5 litre; $100 \mathrm{~cm}$ long $\times 8.5 \mathrm{~cm}$ diam.; fitted with a porosity 2 sinter) and a silica spectrophotometer cell (capacity $4 \mathrm{ml} ; 1 \mathrm{~cm}$ light-path) fitted with a dual-bulb (each $4 \mathrm{ml}$ capacity) Thunberg head and with an Araldite-sealed brass hollow screw in the side arm, were made by Northern Scientific, York, Yorks., U.K. Argon ( $99.9 \%$ pure), pure $\mathrm{O}_{2}$, argon containing $1 \% \mathrm{H}_{2}$ and an argon- $\mathrm{O}_{2}$ gas mixer (model 100 ) were from Air Products Ltd., Rotherham, Yorks., U.K. Hydroxyapatite was prepared according to Tiselius et al. (1956) and stored at room temperature in $1 \mathrm{~mm}$-potassium phosphate buffer, pH6.8.

Benzylamine, obtained from Koch-Light Laboratories Ltd., Colnbrook, Bucks., U.K., was converted into the hydrochloride and recrystallized three times from ethanol-water before use. Benzyl alcohol was purified from benzaldehyde by treatment with lithium aluminium hydride followed by distillation under $\mathrm{N}_{2}$ at reduced pressure. Comparison of $E_{285}$ with a sample taken from a freshly opened bottle of AnalaR benzaldehyde showed that the benzyl alcohol contained less than $0.006 \%$ of benzaldehyde. $\mathrm{H}_{2} \mathrm{O}_{2}$ was standardized by permanganate titration (Kolthoff \& Sandell, 1952). Enzyme and substrates for the $\mathrm{NH}_{3}$ assay were bought from C. F. Boehringer und Soehne, Mannheim, Germany.

\section{Enzyme isolation}

The procedure used was a modification of that published by Buffoni \& Blaschko (1964). Only those steps which have been changed will be described fully.

Step I. Separation of pig plasma. As a routine 15 litres of plasma were obtained from a batch of 22 litres of fresh pig's blood. Subsequent steps were carried out at $4^{\circ} \mathrm{C}$.

Step II. $\left(\mathrm{NH}_{4}\right)_{2} \mathrm{SO}_{4}$ precipitation. The $\left(\mathrm{NH}_{4}\right)_{2} \mathrm{SO}_{4}$ fraction precipitating between 35 and $55 \%$ saturation was dissolved in $0.01 \mathrm{M}$-potassium phosphate 
buffer, pH7.0, and desalted on a Sephadex G-25 column ( 5 litres bed vol.), which had been previously equilibrated with the $0.01 \mathrm{M}$-phosphate buffer, pH7.0.

Step III. DEAE-cellulose chromatography. By increasing the bed volume from 0.7 to 4.0 litres a whole batch (see step I) could be chromatographed in one operation.

Step IV. The desalted material from step III [desalted on a Sephadex G-25 column (1.5 litre bed vol.) instead of by dialysis] was adsorbed on a column (1.5 litres bed vol.) of DEAE-Sephadex equilibrated with $0.005 \mathrm{M}$-potassium phosphate buffer, pH7.0. A linear elution gradient (4 litres of $0.2 \mathrm{M}-\mathrm{NaCl}$ in the $0.005 \mathrm{M}$-phosphate buffer, $\mathrm{pH} 7.0$, in the reservoir and 4 litres of the $0.005 \mathrm{M}$-phosphate buffer, pH7.0, in the mixing chamber) was applied to the column. Fractions were analysed for enzymic activity and for ceruloplasmin, the latter by measuring the $E_{605}$ (Curzon, 1966). Although the ceruloplasmin peaked before the amine oxidase, a complete separation of the two proteins could not be achieved.

Step V. Hydroxyapatite fractionation. Column chromatography of the enzyme on hydroxyapatite as described by Buffoni \& Blaschko (1964) was unsatisfactory since, because of slow column flow rates, elution of the enzyme required 10 days. A batchwise hydroxyapatite procedure gave good increases in specific activity and completely separated the enzyme from ceruloplasmin. The desalted material from step IV was treated with $210 \mathrm{ml}$ of hydroxyapatite, $550 \mathrm{ml}$ of $0.006 \mathrm{M}$-potassium phosphate buffer, pH6.8, added and the whole stirred for $40 \mathrm{~min}$. The supernatant after centrifugation ( $200 \mathrm{~g}$ for $5 \mathrm{~min}$ ) was decanted and the hydroxyapatite extracted a further three times as above with $350 \mathrm{ml}$ portions of the same buffer. All the supernatants were combined, clarified by centrifugation $(15 \mathrm{~min}$ at $22000 \mathrm{~g})$ and brought to $55 \%$ saturation with solid $\left(\mathrm{NH}_{4}\right)_{2} \mathrm{SO}_{4}$, the $\mathrm{pH}$ being adjusted to 7.0 with aq. $\mathrm{NH}_{3}$. The precipitate was left overnight, centrifuged and dissolved in $0.05 \mathrm{M}$-potassium phosphate buffer, $\mathrm{pH}$ 7.0. The hydroxyapatite was further extracted with
$4 \times 350 \mathrm{ml}$ of $0.06 \mathrm{M}$-potassium phosphate buffer, pH6.8, by the same procedure described above, the supernatants were combined and brought to $55 \%$ saturation with $\left(\mathrm{NH}_{4}\right)_{2} \mathrm{SO}_{4}$. This solution, containing 14.6 units of enzyme with specific activity 0.068 unit/mg of protein, was added to the next batch of enzyme after step IV. Some ceruloplasmin still remained adsorbed to the hydroxyapatite after the $0.06 \mathrm{M}$-phosphate buffer, pH6.8, elution but could readily be eluted with $0.2 \mathrm{M}$-potassium phosphate buffer, pH6.8.

Step VI. Crystallization. The procedure described by Buffoni \& Blaschko (1964) was followed.

The whole purification procedure is summarized in Table 1.

\section{Methods}

Protein concentrations. The $260 / 280 \mathrm{~nm}$ method of Warburg \& Christian (1941) was used for all kinetic experiments. Gravimetric measurement of protein showed that the true protein concentration is $0.75 \times$ the $260 / 280 \mathrm{~nm}$ method value. The corrected protein concentration was used in the tests for benzaldehyde and $\mathrm{NH}_{3}$ under anaerobic conditions.

Measurement of enzymic activity. A Unicam SP.700 (Pye Unicam, Cambridge, Cambs., U.K.) with absorbance-scale expansion and with a cell holder thermostatically controlled to $\pm 0.1^{\circ} \mathrm{C}$ by a Haake Cryostat KT62 (Haake, Berlin, Germany) was used to monitor benzaldehyde production at $250 \mathrm{~nm}$ (Tabor et al., 1954). One unit of benzylamine oxidase activity is defined as the amount of enzyme which catalyses the transformation of $1 \mu \mathrm{mol}$ of substrate/min at $25.0^{\circ} \mathrm{C}$ under the standard assay conditions of Tabor et al. (1954).

The Unicam SP. 700 was also used to study difference spectra on the enzyme between 220 and $300 \mathrm{~nm}$ and for the studies on anaerobic production of benzaldehyde and $\mathrm{NH}_{3}$. For the $\mathrm{NH}_{3}$ assay, an SP.750 scale-expansion unit was attached since the $\Delta E$ was small. $\mathrm{O}_{2}$ concentrations were measured using a Clark-type electrode (Rank Brothers, Botti-

Table 1. Purification procedure for pig plasma benzylamine oxidase

For details see the text.

\begin{tabular}{|c|c|c|c|c|c|c|c|}
\hline Step & Fraction & $\begin{array}{l}\text { Volume } \\
\text { (ml) }\end{array}$ & $\begin{array}{l}\text { Protein } \\
\text { (mg) }\end{array}$ & $\begin{array}{c}10^{3} \times \text { Specific } \\
\text { activity } \\
\text { (units } / \mathrm{mg} \\
\text { of protein) }\end{array}$ & $\begin{array}{l}\text { Total } \\
\text { activity } \\
\text { (units) }\end{array}$ & Purification & $\begin{array}{l}\text { Yield } \\
(\%)\end{array}$ \\
\hline I & Plasma & 15000 & 1125000 & 0.225 & 254 & 1 & 100 \\
\hline II & $\begin{array}{c}35-55 \% \text {-saturation } \\
\left(\mathrm{NH}_{4}\right)_{2} \mathrm{SO}_{4}\end{array}$ & 2770 & 174500 & 0.720 & 125 & 3.2 & 49 \\
\hline III & DEAE-cellulose & 440 & 14500 & 4.15 & 60 & 18.5 & 23.5 \\
\hline IV & DEAE-Sephadex & 227 & 2880 & 20.3 & 58.5 & 90.0 & 22.5 \\
\hline V & Hydroxyapatite & 19.2 & 350 & 110 & 38.5 & 490 & 15.2 \\
\hline VI & Crystallization & 13.0 & 250 & 134 & 33.5 & 600 & 13.2 \\
\hline
\end{tabular}


sham, Cambs., U.K.) incorporated into the circuit described by Estabrook (1967). The circuit was modified (Taylor, 1971) to give the $10 \times$ scale expansion necessary for $K_{m}$ determinations on benzyl alcohol.

\section{General kinetic properties}

I. Michaelis constants for benzylamine and $\mathrm{O}_{2}$. (a) Benzylamine. The benzylamine concentration was varied over the range $0.0466-3.33 \mathrm{~mm}$ in airsaturated solution $\left(0.185 \mathrm{mM}_{-}-\mathrm{O}_{2}\right)$ and $\mathrm{O}_{2}$-saturated solution $\left(1.1 \mathrm{mM}^{-\mathrm{O}_{2}}\right)$. To ensure that this latter concentration of $\mathrm{O}_{2}$ did saturate the enzyme, the rates of reaction of an assay mixture equilibrated at atmospheric pressure for $70 \mathrm{~s}$ with a $50 \%$ argon- $\mathrm{O}_{2}$ mixture and with pure $\mathrm{O}_{2}$ were compared. The rates were identical.

(b) $\mathrm{O}_{2}$. The $\mathrm{O}_{2}$ concentration was varied over the range $0.050-1.1 \mathrm{mM}$ at a fixed benzylamine concentration of $3.33 \mathrm{~mm}$. The experimental procedure for measuring dissolved $\mathrm{O}_{2}$ concentration is given in the section describing initial-velocity measurements on the enzyme.

II. Dependence of rate on ionic strength. Kinetic runs were carried out by using standard assay mixtures at $\mathrm{pH} 7.4$ and $37^{\circ} \mathrm{C}$. The ionic strength was varied by using sodium phosphate buffers with molarity from $0.1 \mathrm{~mm}$ to $1.0 \mathrm{M}$.

III. Effect of pH on the apparent maximum velocity and apparent Michaelis constant for benzylamine. The benzylamine concentration was varied over the range $0.112-3.33 \mathrm{mM}$ at each $\mathrm{pH}(5.8,6.6,7.4,8.2$ and 9.0) in $0.05 \mathrm{M}$-sodium phosphate buffer at $37^{\circ} \mathrm{C}$.

\section{Initial-velocity studies}

These experiments were carried out at various fixed $\mathrm{O}_{2}$ concentrations with changing benzylamine concentrations and at various fixed benzylamine concentrations with changing $\mathrm{O}_{2}$ concentrations, the temperature being $37^{\circ} \mathrm{C}$. The assay mixture $(1.70 \mathrm{ml}$ of $0.1 \mathrm{M}$-sodium phosphate buffer, $\mathrm{pH} 7.4$, benzylamine and water to a final volume of $2.90 \mathrm{ml}$ ) was contained in a spectrophotometer cell fitted with a serum cap (Subaseal Ltd., Barnsley, Yorks., U.K.). The gas was introduced either directly from the $\mathrm{O}_{2}$ cylinder or from the argon- $\mathrm{O}_{2}$ gas mixer through a stainless steel serum needle (Thackray Ltd., Leeds, Yorks., U.K.) for $60 \mathrm{~s}$, then the enzymic reaction was initiated by the addition of enzyme $(0.10 \mathrm{ml})$ from a syringe (Hamilton 705). Passage of gas through the solution was continued for a further $10 \mathrm{~s}$ to ensure complete mixing of enzyme and substrate, then the needles were removed and the holes in the serum cap filled with Evostik (Evode Ltd., Stafford, Staffs., U.K.). It was known from a control experiment that the assay mixture became saturated with pure $\mathrm{O}_{2}$ in

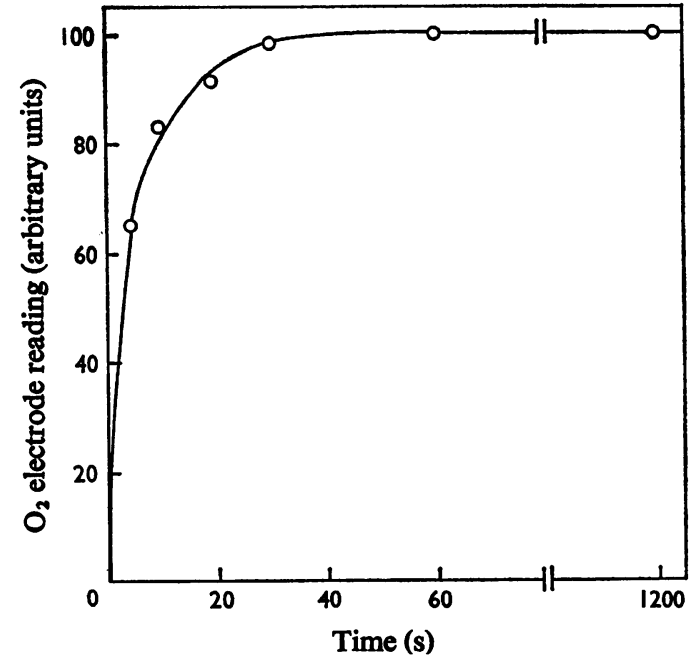

Fig. 1. Experiment to determine the time taken to saturate a solution (vol. $3 \mathrm{ml})$ with pure $\mathrm{O}_{2}$ at atmospheric pressure and at $37^{\circ} \mathrm{C}$

For details see the text.

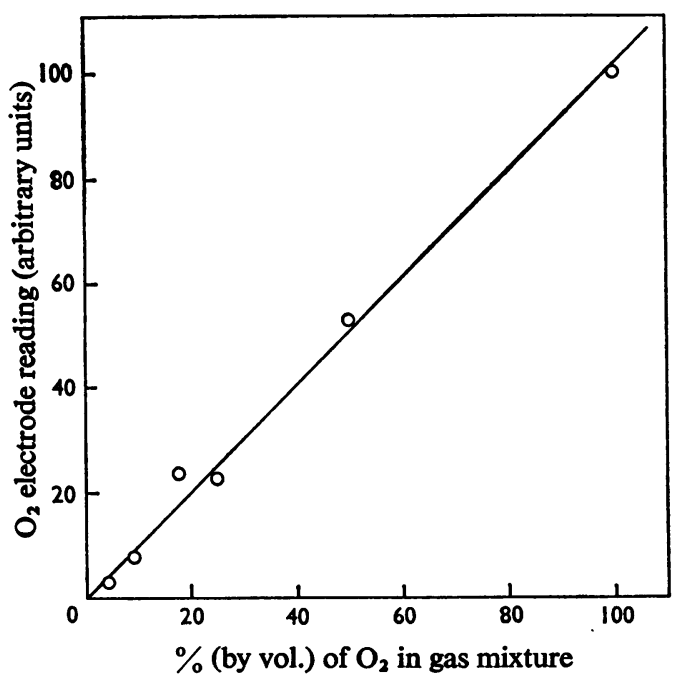

Fig. 2. Determination of dissolved $\mathrm{O}_{2}$ concentration after bubbling argon- $\mathrm{O}_{2}$ mixtures of various compositions through a solution (vol. $3 \mathrm{ml}$ ) at $37^{\circ} \mathrm{C}$

For details see the text.

60 s (Fig. 1). The absolute $\mathrm{O}_{2}$ concentrations corresponding to the different argon- $\mathrm{O}_{2}$ mixtures and of air were determined polarographically. The gas was 
bubbled through an assay mixture containing no enzyme at $37^{\circ} \mathrm{C}$ for $70 \mathrm{~s}$ (Fig. 2). Since the $\mathrm{O}_{2}$ content of air-saturated water at $37^{\circ} \mathrm{C}$ is known [Handbook of Chemistry and Physics, 33rd edn., 1951-1952, p. 1481 ; Chemical Rubber Publishing Co., Cleveland, Ohio] the $\mathrm{O}_{2}$ concentration can be expressed in $\mathrm{mol} /$ litre.

\section{Product inhibition studies}

The general procedure was similar to that described for the initial-velocity studies; each product in turn was added to the assay mixture under the experimental conditions summarized in the legends to Figs. 8-19. For the experiments where saturating conditions of the fixed substrate were used, the concentrations were $3.3 \mathrm{~mm}$ and $1.1 \mathrm{~mm}$ for benzylamine and $\mathrm{O}_{2}$ respectively. These concentrations are approximately an order of magnitude greater than the $K_{m}$ values. The concentration of product inhibitor used under saturating conditions of fixed substrate was equal to or less than $10 \times$ that used under non-saturating conditions. Practical difficulties were encountered with $\mathrm{NH}_{3}$ and with benzaldehyde. To observe inhibition with $\mathrm{NH}_{3}$, it was necessary to compare the rate of benzaldehyde production in $1 \mathrm{M}$-ammonium phosphate buffer, pH7.4, with the rate in $1 \mathrm{M}$-sodium phosphate buffer, pH7.4. The conductivities of these two buffers were identical, which eliminated the possibility that the effect was due to a difference in ionic strength. For the inhibition studies with benzaldehyde, a saturated aqueous solution of benzaldehyde was prepared (a freshly opened bottle of this reagent was used since benzaldehyde is readily converted into benzoic acid on storage). The concentrations of benzaldehyde used in the experiments were calculated based on a $\epsilon$ at $250 \mathrm{~nm}$ of 12000 litre. $\mathrm{mol}^{-1} \cdot \mathrm{cm}^{-1}$ (Dearden \& Forbes, 1958). Under conditions of saturating benzylamine concentration $\left(\mathrm{O}_{2}\right.$ concentration changing) and saturating $\mathrm{O}_{2}$ concentration (benzylamine concentration changing) the concentrations of benzaldehyde needed to give inhibition were too great to be measured by using the

Table 2. $\mathrm{O}_{2}$ concentration in $0.6 \mathrm{ml}$ of assay mixture after bubbling of various $\mathrm{O}_{2}$-argon mixtures for $30 \mathrm{~s}$ through the solution

For details see the text.

$\begin{array}{cc}\begin{array}{c}\% \text { of } \mathrm{O}_{2} \text { in } \\ \mathrm{O}_{2} \text {-argon mixture }\end{array} & \\ 100 & \text { [Dissolved } \mathrm{O}_{2} \text { ] }(\mathrm{mM}) \\ 16.7 & 1.1 \\ 9.1 & 0.4 \\ 4.7 & 0.24 \\ & 0.2\end{array}$

standard assay procedure in $1 \mathrm{~cm}$-light-path spectrophotometer cells because of the high $E_{250}$ of benzaldehyde. For these experiments, therefore, the assay mixture was scaled down to give a final volume of $0.6 \mathrm{ml}$ and the reaction was carried out in $0.2 \mathrm{~cm}$-lightpath spectrophotometer cells. The amount of $\mathrm{O}_{2}$ dissolved in $0.6 \mathrm{ml}$ of assay mixture at $37^{\circ} \mathrm{C}$ when $\mathrm{O}_{2}$-argon mixtures of various compositions were bubbled for 30s through the solution was determined polarographically as described more fully for the initial-velocity studies; the results of this calibration are summarized in Table 2.

\section{Analysis of kinetic data}

Double-reciprocal plots of experimental results were obtained by using the weighted linear-regression computer procedure described by Wilkinson (1961). Secondary plots of slope against inhibitor concentration and intercept against inhibitor concentration were made and the $K_{t}$ slopes and $K_{t}$ intercepts determined.

\section{Anaerobic product analysis}

For clarity the full method is included with the results of these experiments.

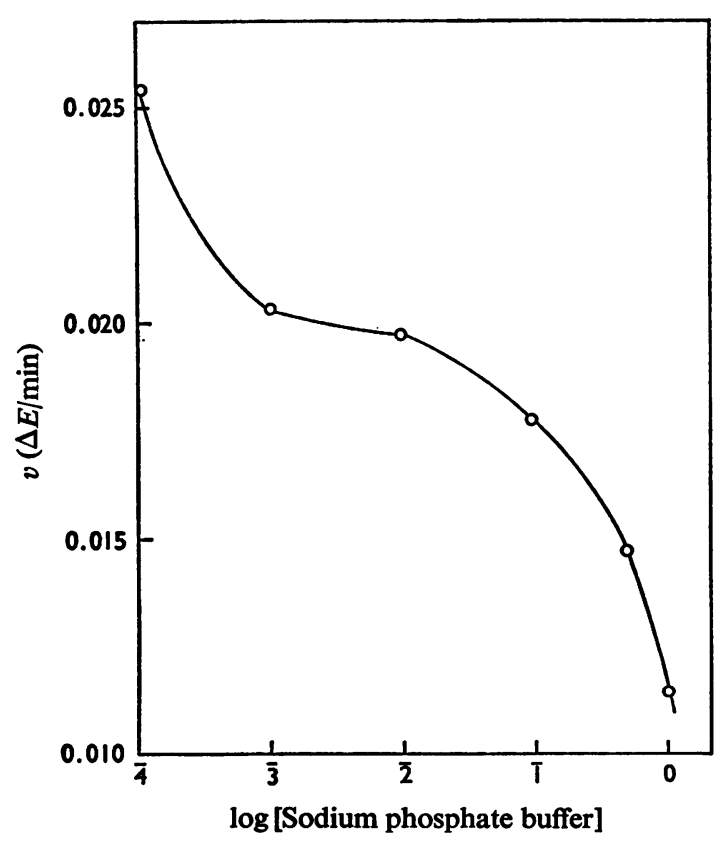

Fig. 3. Effect of buffer strength on pig plasma benzylamine oxidase activity

For details see the text. 


\section{Results}

\section{General kinetic properties}

I. Michaelis constants for benzylamine and $\mathrm{O}_{2}$. The apparent Michaelis constants at $37^{\circ} \mathrm{C}$ for benzylamine in $\mathrm{O}_{2}$-saturated solutions is $0.48 \pm 0.035 \mathrm{~mm}$. The Michaelis constant at $37^{\circ} \mathrm{C}$ for $\mathrm{O}_{2}$ is $0.12 \pm 0.022 \mathrm{~mm}$.

II. Dependence of rate on ionic strength. The rate decreased with increasing ionic strength as shown in Fig. 3.

III. Effect of $p H$ on the maximum velocity and apparent Michaelis constant for benzylamine. Doublereciprocal plots of velocity against benzylamine concentration in air-saturated solution were made and the maximum velocity and Michaelis constants were determined at each $\mathrm{pH}$ value. The results are plotted in Figs. 4 and 5.

\section{Initial-velocity studies}

The effect of changing benzylamine concentration at different fixed concentrations of $\mathrm{O}_{2}$ is shown in Fig. 6 and of changing $\mathrm{O}_{2}$ concentration at different fixed concentrations of benzylamine in Fig. 7. The apparent Michaelis constant/apparent maximum velocity ratios are shown in Table 3.

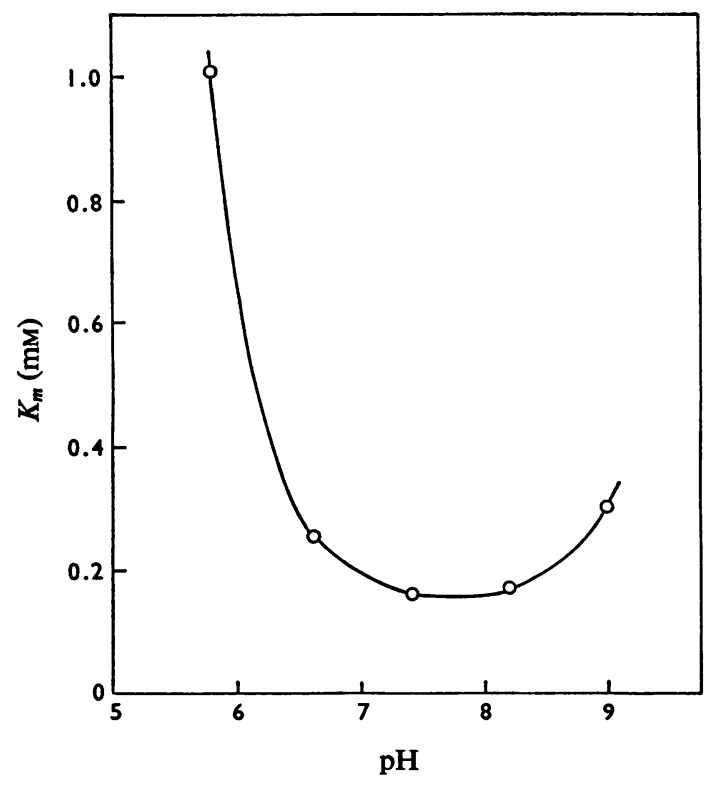

Fig. 4. Dependence of apparent $K_{m}$ value on $p H$

Sodium phosphate buffer $(0.05 \mathrm{M})$ was used at $37^{\circ} \mathrm{C}$. For further details see the text.

\section{Product-inhibition studies}

All the results were recorded as double-reciprocal plots (Figs. 8-19). The values of $K_{t}$ intercept and $K_{t}$ slope are shown in Table 4.

\section{Confirmatory tests}

(i) Production of benzaldehyde from benzylamine under anaerobic conditions. Argon containing $1 \% \mathrm{H}_{2}$ was catalytically deoxygenated by the method described by Swann \& Bray (1972). All metal-glass joints in the apparatus were sealed with Araldite. Analysis of the gas by the method of Sweetser (1967) indicated residual $\mathrm{O}_{2}$ of 9.0p.p.m. which corresponds to an $\mathrm{O}_{2}$ concentration in solution at $25^{\circ} \mathrm{C}$ of $0.011 \mu \mathrm{M}$. This is three orders of magnitude less than the enzyme concentration used. The deoxygenated argon supply was coupled via a three-way tap to the sidearm of an anaerobic spectrophotometer cell fitted with a dual-bulb Thunberg head. The screwed connexion to the side-arm was made gas-tight with a rubber ' $O$ ' ring. Bulb (a) [containing $0.3 \mathrm{ml}$ of benzylamine oxidase $(13.1 \mathrm{mg} / \mathrm{ml})$ ] and bulb (b) [containing $2.65 \mathrm{ml}$ of buffered assay solution plus $50 \mu \mathrm{l}$ of benzylamine hydrochloride solution $(0.2 \mathrm{M})]$ were frozen and made anaerobic by ten cycles of evacuation, thawing, introduction of $\mathrm{O}_{2}$-depleted argon and refreezing. It was known from a separate experiment that benzylamine oxidase did not lose any activity during ten successive freezing and thawing cycles.

Bulb (b) was thawed [keeping bulb (a) frozen] and the contents decanted carefully into the spectrophotometer cell. The measured $E_{250}$ was 0.907 . Bulb (a) was then thawed, the whole cell contents thoroughly mixed and left at $25^{\circ} \mathrm{C}$ for $10 \mathrm{~min}$. The $E_{250}$ after mixing was 1.79 . Since the $E_{250}$ due to the enzyme had been determined to be 0.956 , the calculated $E_{250}$ after mixing, assuming no benzaldehyde liberation, is $0.956+(0.907 \times 2.7 / 3.0)=1.771$. Thus the $\Delta E_{250}$

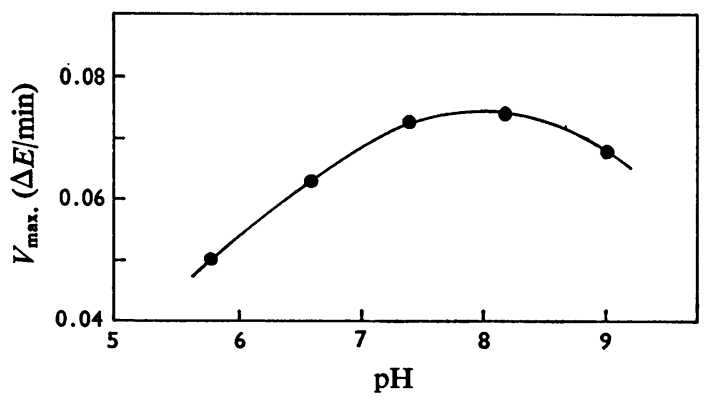

Fig. 5. Dependence of $V_{\max }$. on $p H$

Sodium phosphate buffer $(0.05 \mathrm{M})$ was used at $37^{\circ} \mathrm{C}$. For further details see the text. 
Table 3. $K_{m} / V_{\max }$ ratios for different fixed substrate concentrations

For details see the text.

Fixed concentrations of $\mathrm{O}_{2}$

$\left[\mathrm{O}_{2}\right](\mathrm{mM})$
1.100
0.180
0.097

$\begin{gathered}\text { Apparent } V_{\max } \\ (\Delta E / \min )\end{gathered}$
0.059
0.029
0.019

Apparent $V_{\max }$. $(\Delta E / \mathrm{min})$

0.059

0.013

0.011

0.0081

0.0072

$$
\begin{gathered}
K_{\boldsymbol{m}} / V_{\max .} \text { ratio } \\
0.0087 \\
0.0093 \\
0.0091
\end{gathered}
$$

Fixed concentrations of benzylamine

[Benzylamine] (mM)
3.300
0.170
0.110
0.083
0.067

Apparent $K_{m}(\mathrm{~mm})$
0.192
0.0476
0.0383
0.0326
0.0286

Table 4. Values of $K_{t}$ intercept and $K_{t}$ slope from inhibition studies

For details see the text.

\begin{tabular}{ll} 
Inhibitor & \multicolumn{1}{r}{$\begin{array}{r}\text { Changing } \\
\text { substrate }\end{array}$} \\
$\mathrm{NH}_{3}$ & Benzylamine \\
$\mathrm{NH}_{3}$ & Benzylamine \\
$\mathrm{NH}_{3}$ & $\mathrm{O}_{2}$ \\
$\mathrm{NH}_{3}$ & $\mathrm{O}_{2}$ \\
$\mathrm{H}_{2} \mathrm{O}_{2}$ & Benzylamine \\
$\mathrm{H}_{2} \mathrm{O}_{2}$ & Benzylamine \\
$\mathrm{H}_{2} \mathrm{O}_{2}$ & $\mathrm{O}_{2}$ \\
$\mathrm{H}_{2} \mathrm{O}_{2}$ & $\mathrm{O}_{2}$ \\
Benzaldehyde & Benzylamine \\
Benzaldehyde & Benzylamine \\
Benzaldehyde & $\mathrm{O}_{2}$ \\
Benzaldehyde & $\mathrm{O}_{2}$
\end{tabular}

\begin{tabular}{l}
\multicolumn{1}{c}{ Fixed substrate } \\
$\mathrm{O}_{2}$ non-saturating \\
$\mathrm{O}_{2}$ saturating \\
Benzylamine non-saturating \\
Benzylamine saturating \\
$\mathrm{O}_{2}$ non-saturating \\
$\mathrm{O}_{2}$ saturating \\
Benzylamine non-saturating \\
Benzylamine saturating \\
$\mathrm{O}_{2}$ non-saturating \\
$\mathrm{O}_{2}$ saturating \\
Benzylamine non-saturating \\
Benzylamine saturating \\
* Curved reciprocal plots.
\end{tabular}

$K_{l}$ intercept
(mM)
2300
$*$
-

0.77

0.18

2.6

24

二

$\overline{0.12}$ 


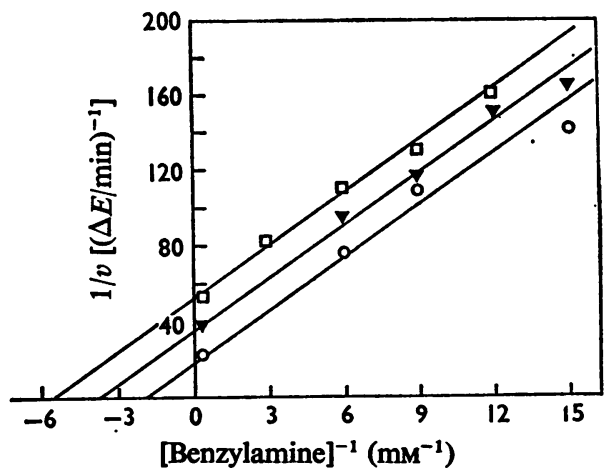

Fig. 6. Initial-velocity study at different fixed $\mathrm{O}_{2}$ concentrations with benzylamine concentration changing

For details see the text. $\mathrm{O}_{2}$ concentrations: $\square$, $0.097 \mathrm{~mm} ; \nabla, 0.18 \mathrm{~mm} ; 0,1.1 \mathrm{~mm}$.

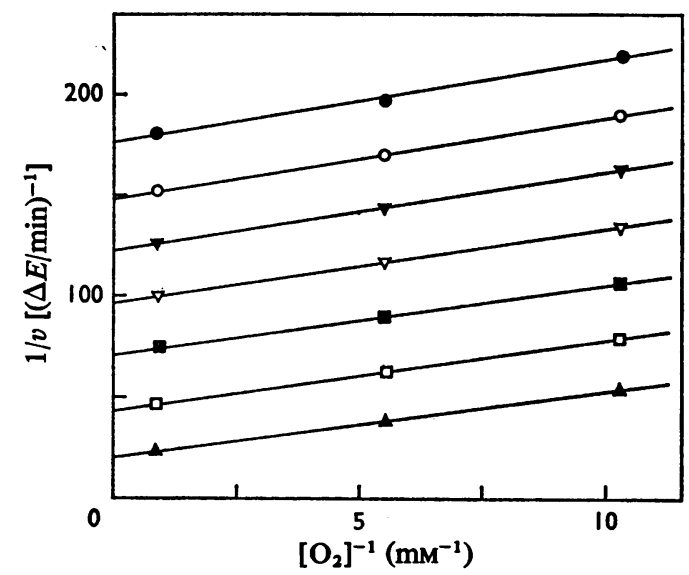

Fig. 7. Initial-velocity study at different fixed benzylamine concentrations with oxygen concentration changing

For details see the text. Benzylamine concentrations: $\triangle, 200 \mathrm{~mm}$; $\square, 20 \mathrm{~mm}$; $10 \mathrm{~mm} ; \nabla, 6 \mathrm{~mm} ; \nabla, 5 \mathrm{~mm}$; o, $4 \mathrm{~mm} ; \bullet, 3.3 \mathrm{~mm}$.

phosphate buffer $(0.4 \mathrm{M}, \mathrm{pH} 7.6)$ and $0.60 \mathrm{ml}$ of glutamate dehydrogenase $(0.5 \mathrm{mg} / \mathrm{ml}, \mathrm{pH} 7.6)$. In experiment (1) $0.35 \mathrm{ml}$ and in experiment (2) $0.70 \mathrm{ml}$ of benzylamine oxidase $(13.1 \mathrm{mg} / \mathrm{ml})$ was used and water was added to give a final volume of $2.95 \mathrm{ml}$ in each case. Bulb (b) contained $0.05 \mathrm{ml}$ of benzylamine $(0.2 \mathrm{M})$.

The solutions were made anaerobic by ten cycles of freezing, evacuation, thawing and introduction of $\mathrm{O}_{2}$-depleted argon and then the contents of bulb (a)

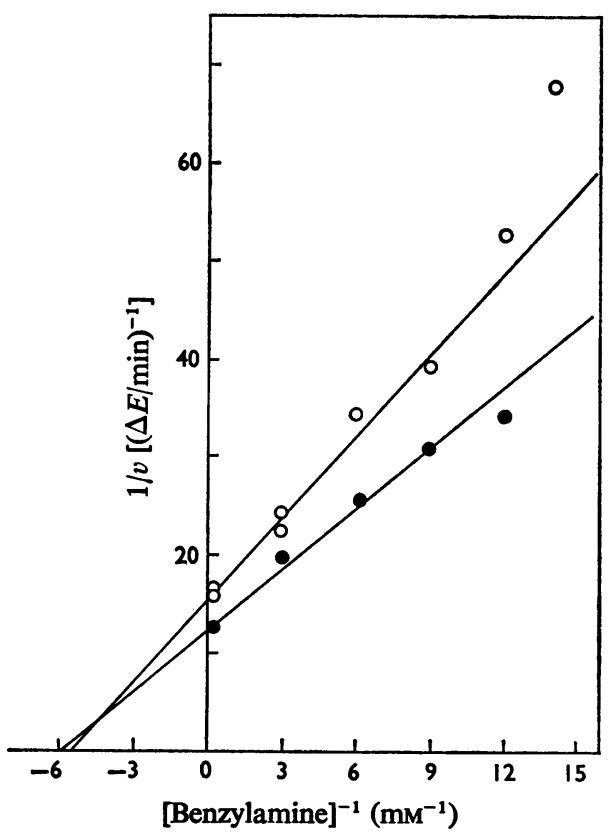

Fig. 8. Product-inhibition study with benzylamine concentration changing, $\mathrm{O}_{2}$ concentration non-saturating and $\mathrm{NH}_{3}$ inhibiting

For details see the text. Buffers were: $0,1.0 \mathrm{M}$ ammonium phosphate, $\mathrm{pH} 7.4 ; \bullet, 1.0 \mathrm{M}$-sodium phosphate, $\mathrm{pH} 7.4$.

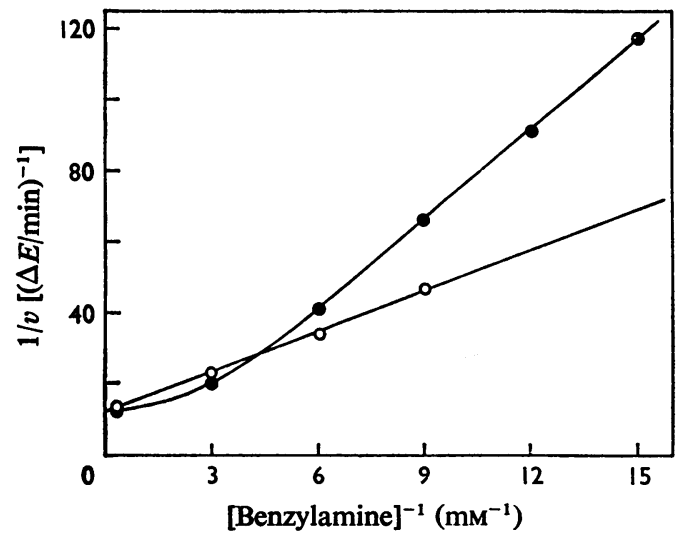

Fig. 9. Product-inhibition study with benzylamine concentration changing, $\mathrm{O}_{2}$ concentration saturating and $\mathrm{NH}_{3}$ inhibiting

For details see the text. Buffers were: $\bullet, 1.0 \mathrm{M}$ ammonium phosphate, pH7.4; $\circ, 1.0 \mathrm{M}$-sodium phosphate, $\mathrm{pH}$ 7.4. 


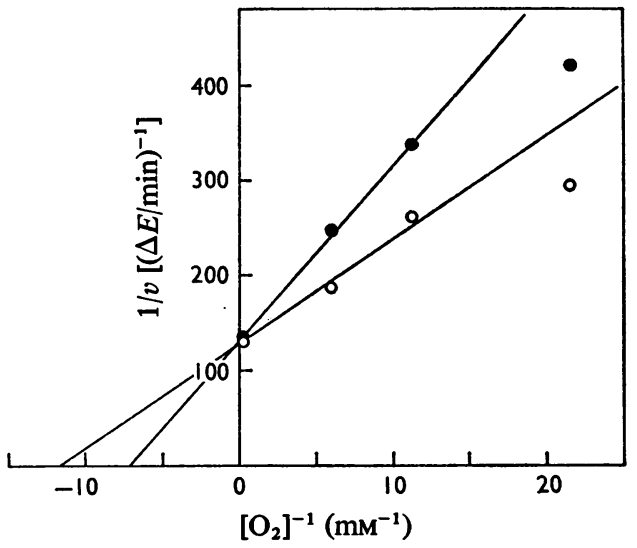

Fig. 10. Product-inhibition study with $\mathrm{O}_{2}$ concentration changing, benzylamine concentration non-saturating and $\mathrm{NH}_{3}$ inhibiting

For details see the text. Buffers were: $\bullet, 1.0 \mathrm{M}$ ammonium phosphate, pH7.4; o, 1.0M-sodium phosphate, $\mathrm{pH} 7.4$.

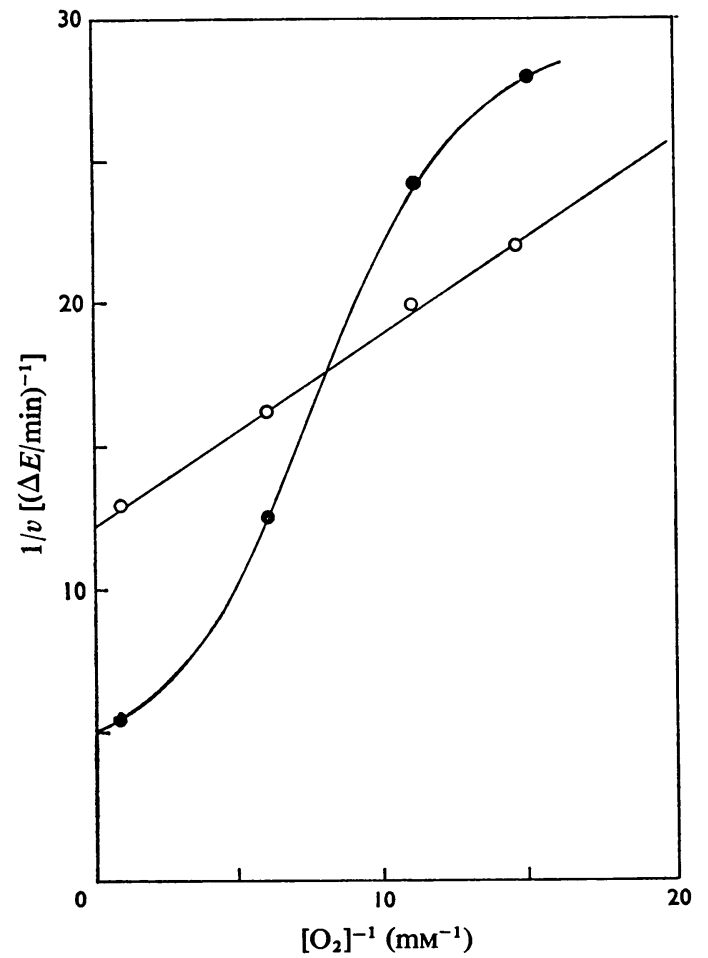

Fig. 11. Product-inhibition study with $\mathrm{O}_{2}$ concentration changing, benzylamine concentration saturating and $\mathrm{NH}_{3}$ inhibiting

For details see the text. Buffers were: $\bullet, 1.0 \mathrm{M}$ ammonium phosphate, $\mathrm{pH} 7.4 ; \mathrm{o}, 1.0 \mathrm{M}$-sodium phosphate, $\mathrm{pH} 7.4$.

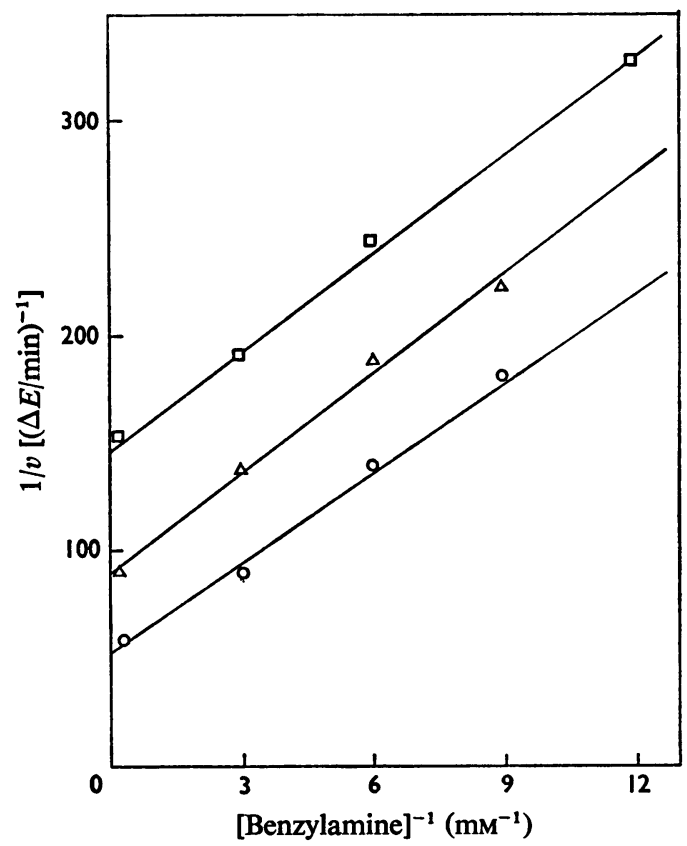

Fig. 12. Product-inhibition study with benzylamine concentration changing, $\mathrm{O}_{2}$ concentration non-saturating and $\mathrm{H}_{2} \mathrm{O}_{2}$ inhibiting

For details see the text. $\mathrm{H}_{2} \mathrm{O}_{2}$ concentrations: $\square$, $1.38 \mathrm{~mm} ; \Delta, 0.55 \mathrm{mM}$; $\circ$, zero (no inhibitor).

were decanted carefully into the spectrophotometer cell [keeping bulb (b) frozen] and the cell allowed to equilibrate to $25^{\circ} \mathrm{C}(5 \mathrm{~min})$ before measuring the rate of NADH disappearance at $340 \mathrm{~nm}$. This rate was uniform over a period of $5 \mathrm{~min}$. (It was known from control experiments that freezing and thawing did not denature either the glutamate dehydrogenase or benzylamine oxidase.) The benzylamine in bulb (b) was thawed and the whole cell contents thoroughly mixed $(3 \mathrm{~min})$ before again measuring the rate of NADH disappearance. As in the control this rate was uniform over $5 \mathrm{~min}$. At the end of the experiment, the cell contents were opened to the air and mixed. An increased rate of $\mathrm{NH}_{3}$ production corresponding to turnover of the benzylamine oxidase was observed.

In experiment (1) the $\Delta E_{340} / \mathrm{min}$ before adding benzylamine was 0.002 and that after adding benzylamine was 0.006 . Thus the $\Delta E_{340} / \mathrm{min}$ due to $\mathrm{NH}_{3}$ produced by the anaerobic reaction between benzylamine oxidase and benzylamine was 0.004 .

From the standard curve (Fig. 20) $\Delta E_{340} / \mathrm{min}$ of 0.004 corresponds to $0.011 \pm 0.001 \mu \mathrm{mol}$ of $\mathrm{NH}_{3} / \mathrm{ml}$. The benzylamine oxidase concentration in the assay was $0.0079 \mu \mathrm{mol} / \mathrm{ml}$. The results obtained from experiment (2) showed that the $\mathrm{NH}_{3}$ released is 


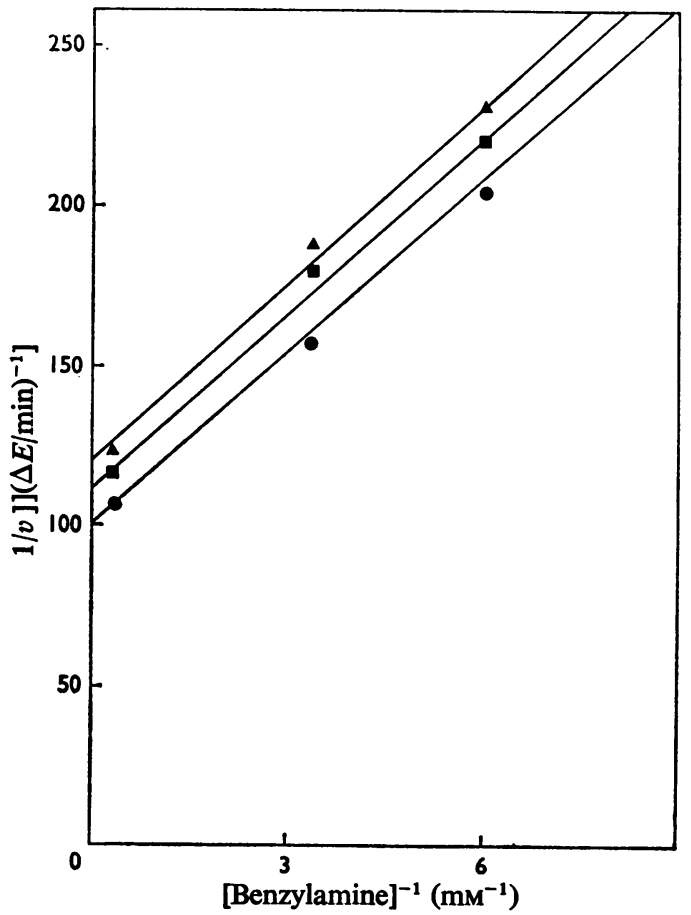

Fig. 13. Product-inhibition study with benzylamine concentration changing, $\mathrm{O}_{2}$ concentration saturating and $\mathrm{H}_{2} \mathrm{O}_{2}$ inhibiting

For details see the text. $\mathrm{H}_{2} \mathrm{O}_{2}$ concentrations: $\Delta, 1.38 \mathrm{~mm} ; \square, 0.55 \mathrm{mM}$; $\bullet$, zero (no inhibitor).

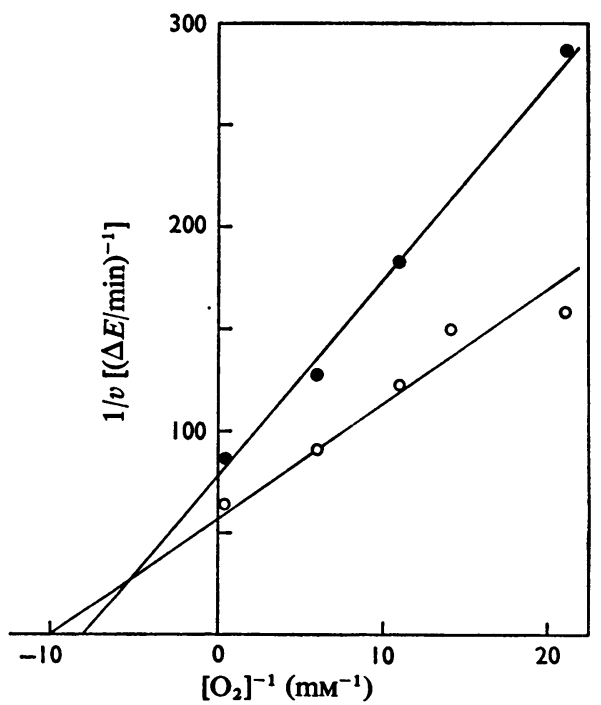

Fig. 14. Product-inhibition study with $\mathrm{O}_{2}$ concentration changing, benzylamine concentration non-saturating and $\mathrm{H}_{2} \mathrm{O}_{2}$ inhibiting

For details see the text. $\mathrm{H}_{2} \mathrm{O}_{2}$ concentrations: $\bullet, 1.4 \mathrm{~mm}$; o, zero (no inhibitor).

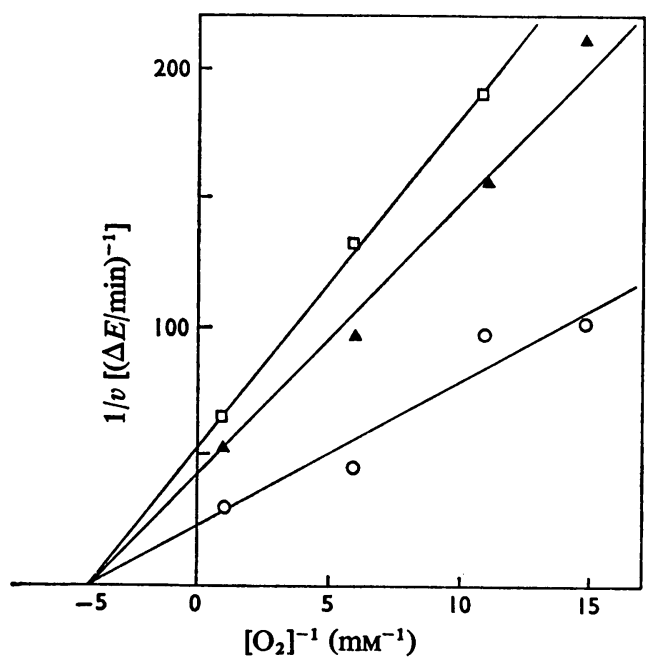

Fig. 15. Product-inhibition study with $\mathrm{O}_{2}$ concentration changing, benzylamine concentration saturating and $\mathrm{H}_{2} \mathrm{O}_{2}$ inhibiting

For details see the text. $\mathrm{H}_{2} \mathrm{O}_{2}$ concentrations: $\square, 13.8 \mathrm{mM}$; $\triangle, 5.5 \mathrm{~mm}$; o, zero (no inhibitor).

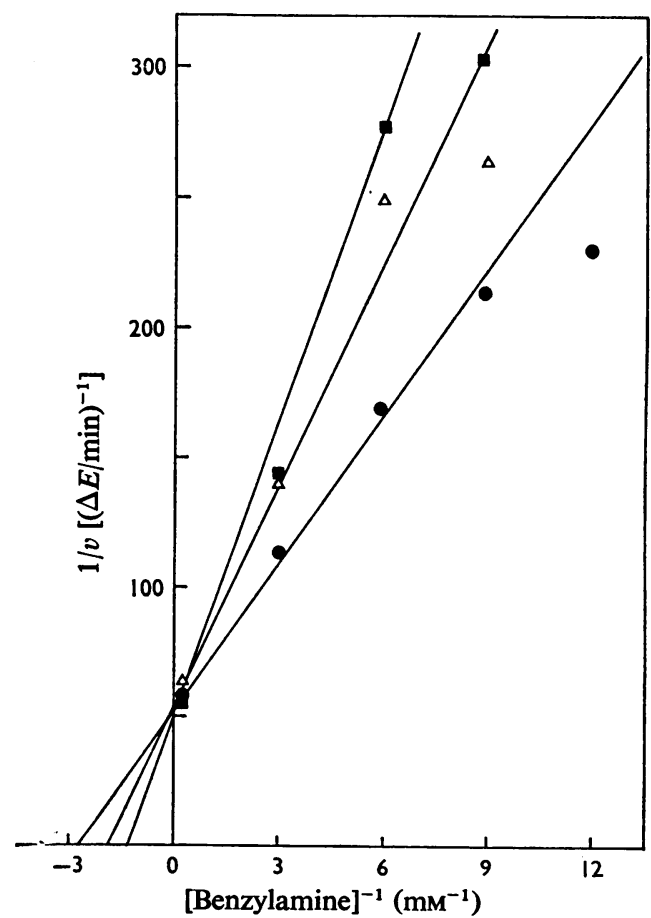

Fig. 16. Product-inhibition study with benzylamine concentration changing, $\mathrm{O}_{2}$ concentration non-saturating and benzaldehyde inhibiting

For details see the text. Benzaldehyde concentrations: $\square, 0.14 \mathrm{~mm} ; \triangle, 0.072 \mathrm{~mm} ; \bullet$, zero (no inhibitor). 


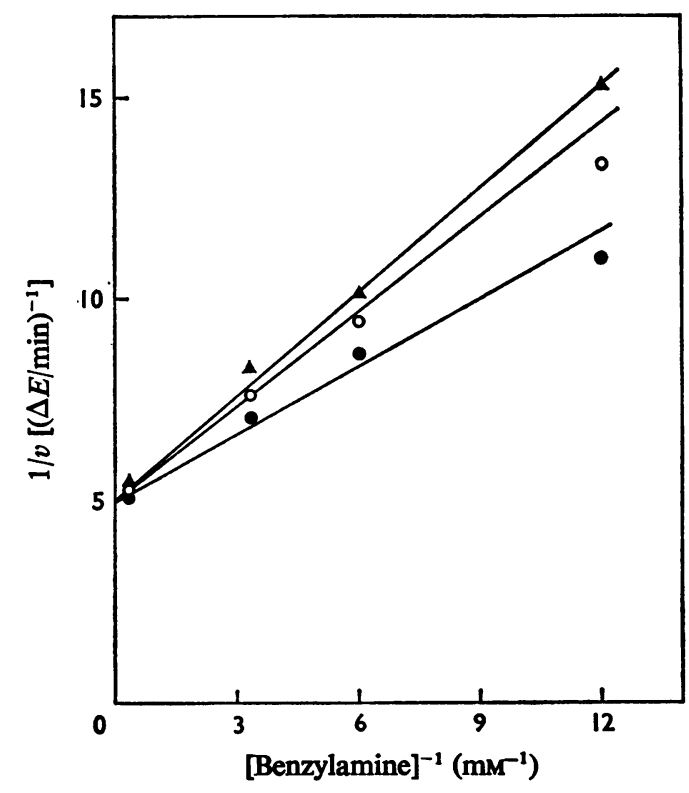

Fig. 17. Product-inhibition study with benzylamine concentration changing, $\mathrm{O}_{2}$ concentration saturating and benzaldehyde inhibiting

For details see the text. Benzaldehyde concentrations: o, $0.57 \mathrm{~mm} ; \Delta, 0.71 \mathrm{~mm}$; $\bullet$, zero (no inhibitor).

dependent on the benzylamine oxidase concentration (Fig. 21). It is concluded that $\mathrm{NH}_{3}$ in excess of $1 \mathrm{~mol} /$ mol of enzyme is released from benzylamine under anaerobic conditions.

(iii) Benzyl alcohol as a substrate for benzylamine oxidase. Owing to the high initial $E_{250}$ of benzyl alcohol, this experiment was carried out by using an $\mathrm{O}_{2}$ electrode. The $K_{m}$ at $37^{\circ} \mathrm{C}$ in air-saturated buffer was $10 \mathrm{~mm}$ (Fig. 22).

\section{Discussion}

\section{General kinetic properties}

Effect of ionic strength. It is noteworthy that whereas the initial velocity decreases with increasing ionic strength for pig plasma benzylamine oxidase, the initial velocity increases with increasing ionic strength up to a maximum of approx. $0.5 \mathrm{M}$ for the beef plasma enzyme (Yamada \& Yasunobu, 1962).

Effect of $p H$. The dependence of the $K_{m}$ value for benzylamine on $\mathrm{pH}$ for the pig plasma enzyme is of a similar form to that of the rabbit plasma enzyme (McEwan, 1965). The variation of $V_{\max }$. with $\mathrm{pH}$ is somewhat different in that the $V_{\max }$. for the rabbit enzyme reaches a constant value at pH8.0 (McEwan, 1965) whereas above pH8.2 the $V_{\max }$. for the pig enzyme decreases. A similar analysis of kinetic data

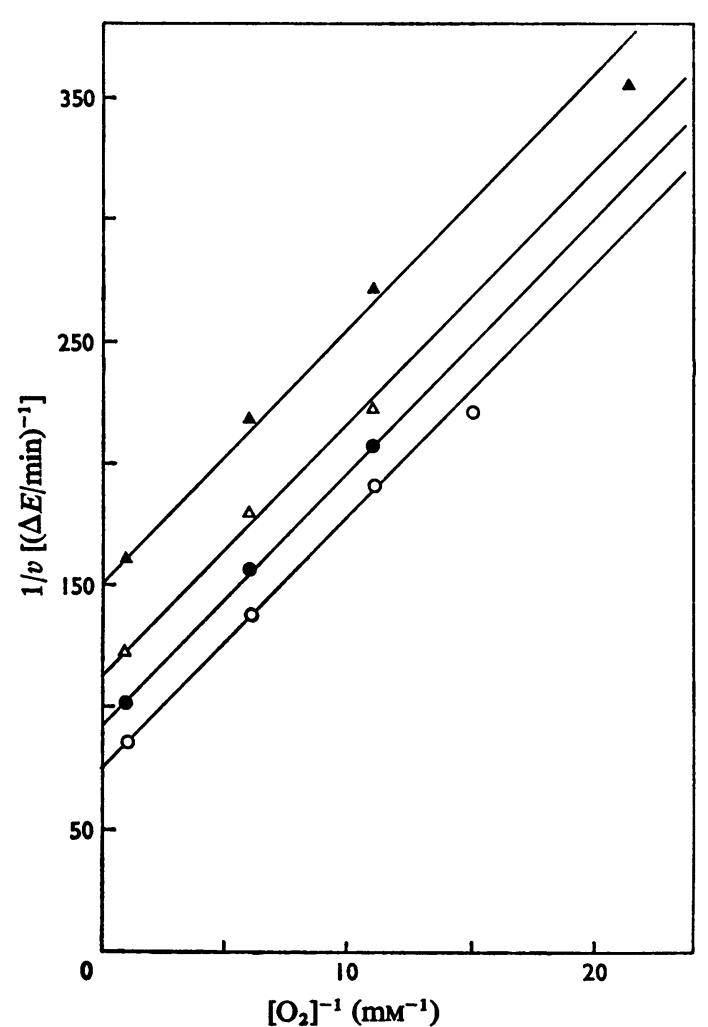

Fig. 18. Product-inhibition study with $\mathrm{O}_{2}$ concentration changing, benzylamine concentration non-saturating and benzaldehyde inhibiting

For details see the text. Benzaldehyde concentrations: $\triangle, 0.098 \mathrm{~mm} ; \Delta, 0.049 \mathrm{~mm} ; \bullet, 0.019 \mathrm{~mm}$; o, zero (no inhibitor).

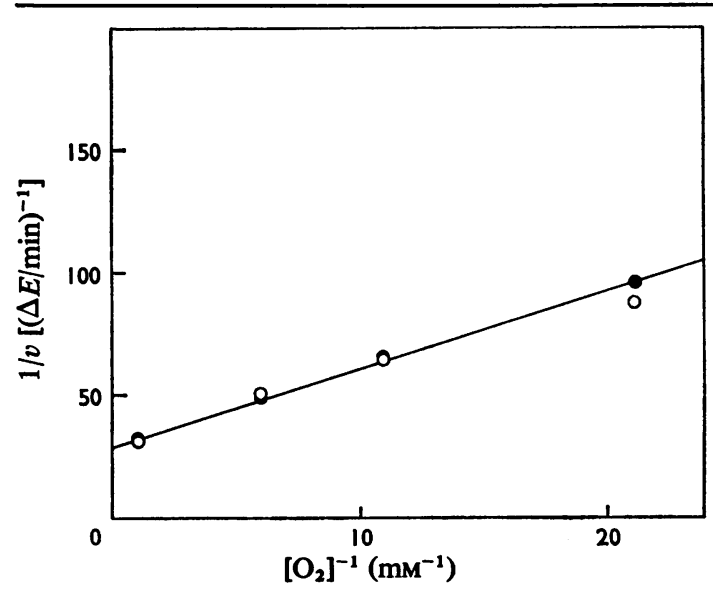

Fig. 19. Product-inhibition study with $\mathrm{O}_{2}$ concentration changing, benzylamine concentration saturating and benzaldehyde inhibiting

For details see the text. Benzaldehyde concentrations: $0,0.45 \mathrm{~mm}$; $\bullet$, zero (no inhibitor). 


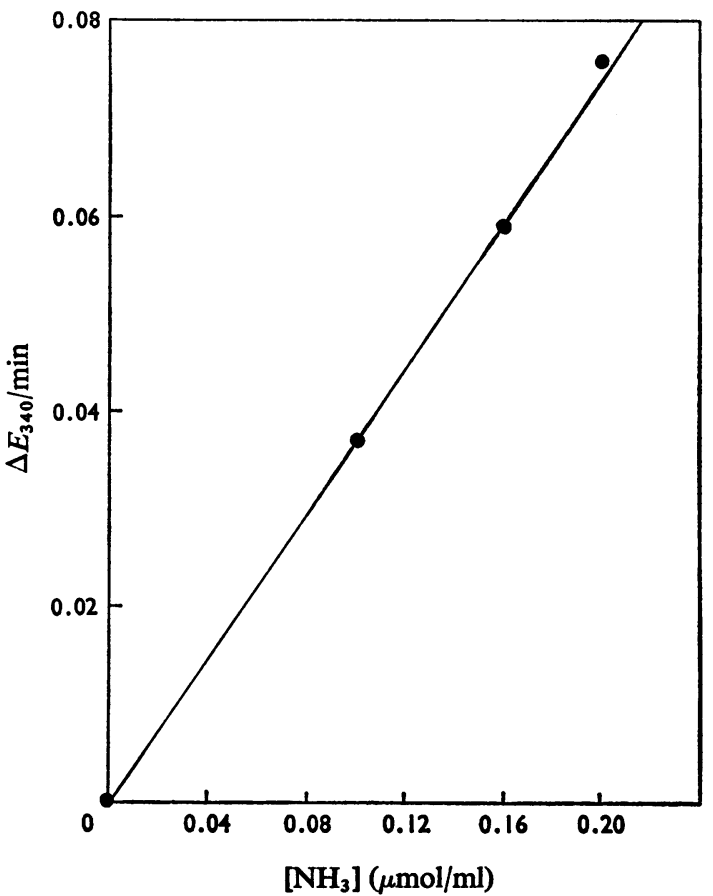

Fig. 20. Standard curve for $\mathrm{NH}_{3}$ concentration determination at $25^{\circ} \mathrm{C}$

For details see the text.

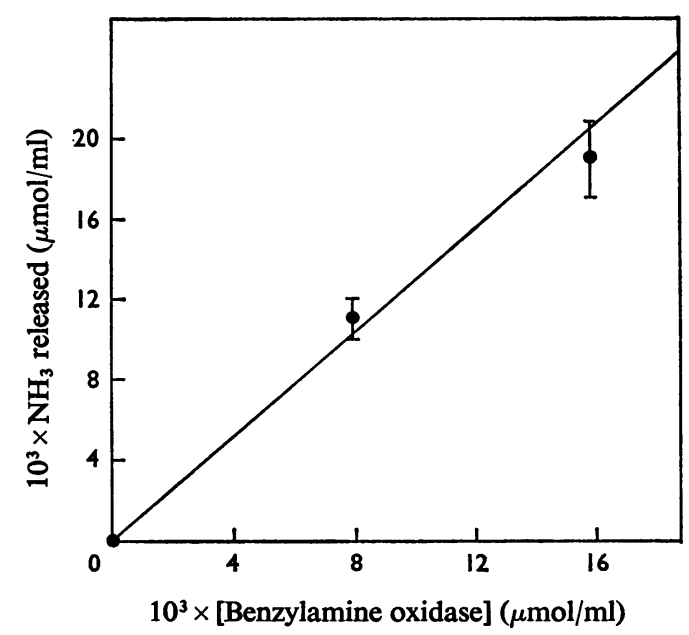

Fig. 21. Dependence of $\mathrm{NH}_{3}$ liberated from benzylamine by benzylamine oxidase on the enzyme concentration

For details see the text. The bars represent limits of errors.

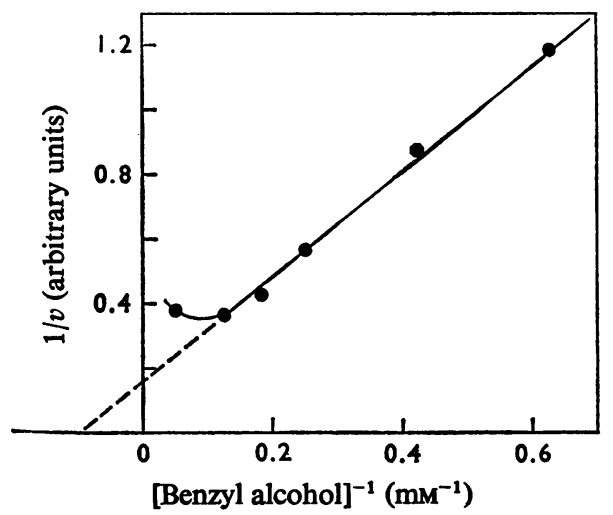

Fig. 22. $K_{m}$ value determination for benzyl alcohol in air at $37^{\circ} \mathrm{C}$

For details see the text.

to that applied by McEwan (1965) for the rabbit enzyme was used in the present study. For the rabbit enzyme, it is assumed that the $\left[\mathrm{H}^{+}\right]$dependence of $K_{m}$ is associated with the forward rate constant for enzyme-substrate complex formation and not from subsequent reactions of this complex. The reactants for the rabbit enzyme are assumed to be the protonated amine substrate and an unprotonated site on the enzyme. McEwan (1965) gives an equation:

$K_{m}=\bar{K}_{m}\left[1+\operatorname{antilog}\left(\mathrm{p} K_{a}^{\mathrm{e}}-\mathrm{pH}\right)+\operatorname{antilog}\left(\mathrm{pH}-\mathrm{p} K_{a}^{\Xi}\right)\right]$

where $\bar{K}_{m}$ refers to the protonated amine and $\mathrm{p} K_{a}^{\mathrm{e}}$ and $\mathrm{p} K_{a}^{s}$ are the $\mathrm{p} K$ values for the enzyme and substrate respectively. The values of $\mathrm{p} K_{a}^{\mathrm{e}}$ and $\mathrm{p} K_{a}^{\mathrm{s}}$ may be obtained from a plot of $K_{m}$ against pH. It can be shown that when the $K_{m}$ value is equal to twice the value of the minimum $K_{m}$, then $\mathrm{pH}=\mathrm{p} K_{a}$.

From Fig. 4 values of $\mathrm{p} K_{a}^{\mathrm{e}}=6.5$ and $\mathrm{p} K_{a}^{\mathrm{s}}=9.0$ may be determined for the pig plasma enzyme. If these values are substituted into equation (1) a constant value of $\bar{K}_{m}$ with changing $\mathrm{pH}$ value results. Since the acid-dissociation constant for benzylamine is 9.37 (Carothers et al., 1927), it may be that the higher $\mathrm{pH}$-dissociation constant is associated with the enzyme rather than the substrate.

Some conclusions can be drawn from the variation of $V_{\max }$. with pH (Fig. 5). The complete rate equation consistent with the product inhibition data for the pig plasma enzyme yields

$$
\begin{aligned}
K_{m} & =\frac{\left(k_{2}+k_{3}\right) k_{7} k_{9}}{k_{1}\left(k_{3} k_{7}+k_{3} k_{9}+k_{7} k_{9}\right)} \\
V_{\max .} & =\frac{k_{3} k_{7} k_{9} E_{0}}{k_{3} k_{7}+k_{3} k_{9}+k_{7} k_{9}}
\end{aligned}
$$


Both $K_{m}$ and $V_{\max }$. equations contain terms in $k_{3}$, $k_{7}$ and $k_{9}$; the expression for $V_{\max }$ does not, however, contain $k_{1}$, the only rate constant associated with a $\left[\mathrm{H}^{+}\right]$-dependent step in McEwan's (1965) treatment. For the pig plasma enzyme at least and probably for other serum amine oxidases we suggest that it is not valid to assign the $\left[\mathrm{H}^{+}\right]$dependence of the $K_{m}$ value to a specific rate constant $\left(k_{1}\right)$ and to assign the $\left[\mathrm{H}^{+}\right]$ dependence of $V_{\text {max. }}$ to a completely different reaction step. Probably several of the rate constants in the expressions for $K_{m}$ and $V_{\max }$. are associated with $\left[\mathrm{H}^{+}\right]$-dependent reactions.

\section{Initial velocity studies}

From Figs. 6 and 7 it can be seen that the doublereciprocal plots form a family of parallel lines. This suggests that the enzyme operates via a Ping Pong mechanism where release of the first product precedes addition of the second substrate and the enzyme exists in two or more stable forms (Cleland, 1967). Spectral evidence (Buffoni \& Blaschko, 1964) indicates that there are indeed different enzyme forms in the presence and the absence of benzylamine and that the enzyme-benzylamine complex is stable. Addi- tional support for the Ping Pong mechanism comes from the constant ratio of apparent $K_{m}$ value to apparent $V_{\max }$. as the fixed substrate concentration is changed (Cleland, 1963a). See Table 3.

\section{Product inhibition studies}

Each of the products of the reaction was examined as an inhibitor of the initial-velocity dependence on the concentration of each substrate. All possible mechanisms were tested for consistency with the types of inhibition obtained. The only Ping Pong mechanism consistent with the data was:

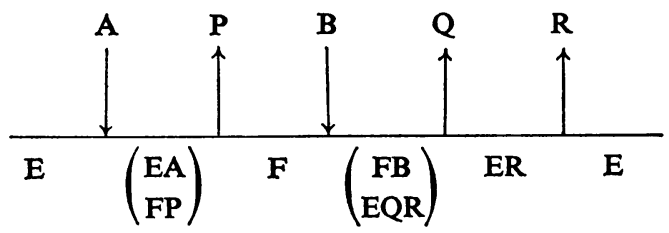

This is mechanism no. 18 of Cleland (1963a) in reverse, and may be called a Uni Uni Uni Bi Ping Pong mechanism. The complete steady-state rate equation is:

$$
\begin{aligned}
v= & \frac{V_{1}\left([\mathrm{~A}][\mathrm{B}]-\frac{[\mathrm{P}][\mathrm{Q}][\mathrm{R}]}{K_{\mathrm{eq}}}\right)}{K_{\mathrm{b}}[\mathrm{A}]+K_{\mathrm{a}}[\mathrm{B}]+[\mathrm{AB}]+\left(\frac{K_{\mathrm{ia}} K_{\mathrm{b}}}{K_{t \mathrm{p}}} \text { or } \frac{V_{1} K_{\mathrm{q}} K_{t \mathrm{r}}}{V_{2} K_{\mathrm{eq}}}\right)[\mathrm{P}]+\frac{K_{\mathrm{b}}}{K_{t \mathrm{p}}}[\mathrm{A}][\mathrm{P}]} \\
& +\frac{V_{1} K_{t \mathrm{p}} K_{\mathrm{r}}[\mathrm{A}][\mathrm{Q}]}{V_{2} K_{\mathrm{eq}} K_{i \mathrm{a}}}+\frac{K_{\mathrm{a}}}{K_{t \mathrm{r}}}[\mathrm{B}][\mathrm{R}]+\frac{V_{1}}{V_{2} K_{\mathrm{eq}}}\left(K_{\mathrm{r}}[\mathrm{P}][\mathrm{Q}]+K_{\mathrm{q}}[\mathrm{P}][\mathrm{R}]+K_{\mathrm{p}}[\mathrm{Q}][\mathrm{R}]+[\mathrm{P}][\mathrm{Q}][\mathrm{R}]\right) \\
& +\frac{V_{1} K_{i \mathrm{p}} K_{\mathrm{r}}}{V_{2} K_{\mathrm{eq}} K_{t \mathrm{a}} K_{i \mathrm{~b}}}[\mathrm{~A}][\mathrm{B}][\mathrm{Q}]+\frac{V_{1} K_{\mathrm{r}}}{V_{2} K_{\mathrm{eq}} K_{l \mathrm{a}}}[\mathrm{A}][\mathrm{P}][\mathrm{Q}]+\frac{V_{1} K_{\mathrm{p}}}{V_{2} K_{\mathrm{eq}} K_{l \mathrm{~b}}}[\mathrm{~B}][\mathrm{Q}][\mathrm{R}]
\end{aligned}
$$

expressed in the form of Cleland's (1963a) constants.

Where

$$
\begin{aligned}
V_{1}= & \frac{k_{3} k_{7} k_{9} E_{0}}{k_{3} k_{7}+k_{3} k_{9}+k_{7} k_{9}} \\
V_{2}= & \frac{k_{2} k_{6} E_{0}}{k_{2}+k_{6}} \\
K_{\mathrm{a}}= & \frac{\left(k_{2}+k_{3}\right) k_{7} k_{9}}{k_{1}\left(k_{3} k_{7}+k_{3} k_{9}+k_{7} k_{9}\right)} \\
K_{\mathrm{b}}= & \frac{k_{3}\left(k_{6}+k_{7}\right) k_{9}}{k_{5}\left(k_{3} k_{7}+k_{3} k_{9}+k_{7} k_{9}\right)} \\
K_{\mathrm{p}}= & \frac{\left(k_{2}+k_{3}\right) k_{6}}{\left(k_{2}+k_{6}\right) k_{4}}, \quad K_{\mathrm{q}}=\frac{k_{2}\left(k_{6}+k_{7}\right)}{\left(k_{2}+k_{6}\right) k_{8}}, \quad K_{\mathrm{r}}=\frac{k_{2} k_{6}}{\left(k_{2}+k_{6}\right) k_{10}} \\
K_{l \mathrm{a}}= & \frac{k_{2}}{k_{1}}, \quad K_{i \mathrm{~b}}=\frac{k_{6}}{k_{5}}, \quad K_{i \mathrm{p}}=\frac{k_{3}}{k_{4}}, \quad K_{i \mathrm{q}}=\frac{k_{7}}{k_{8}}, \quad \text { or } \frac{\left(k_{6}+k_{7}\right) k_{9}}{k_{6} k_{8}} \\
& \text { or } \frac{k_{3} k_{7}+k_{3} k_{9}+k_{7} k_{9}}{k_{3} k_{8}}, \quad K_{i \mathrm{r}}=\frac{k_{9}}{k_{10}} \quad \text { and } K_{\mathrm{eq}}=\frac{k_{1} k_{3} k_{5} k_{7} k_{9}}{k_{2} k_{4} k_{6} k_{8} k_{10}}
\end{aligned}
$$


From simplified forms of this rate equation under the various experimental conditions or from the application of Cleland's rules (Cleland, 1963b) the pattern of inhibition was predicted and this is compared with the experimentally determined pattern (Table 5). The agreement is complete for non-saturating conditions and most saturating conditions. The only discrepancies are those under saturating conditions with $\mathrm{NH}_{3}$ as the product inhibitor when curved reciprocal plots were obtained. An explanation for these discrepancies might be that the assay medium necessary for the $\mathrm{NH}_{3}$ inhibition studies was $1.0 \mathrm{M}$-ammonium phosphate buffer compared with $0.1 \mathrm{M}$ for all other inhibition studies; in $0.1 \mathrm{M}$-ammonium phosphate buffer the inhibition was so slight that the type could not be determined. In view of the observed dependence of the enzyme activity on the ionic strength of the medium (Fig. 3), a different form of the enzyme might be involved. Support for this suggestion comes from a difference spectrum of the enzyme in $0.1 \mathrm{M}$-sodium phosphate buffer and in $1.0 \mathrm{M}$ sodium phosphate buffer where clear indications of a conformational dependence on ionic strength was observed.

\section{Calculation of kinetic constants}

From replots of the slopes and intercepts of the product-inhibition results, various kinetic constants can be derived. These derivations are discussed by Cleland (1970), and details for pig plasma benzylamine oxidase are given by Taylor (1971). Table 6 lists the values of $K_{\mathrm{a}}, K_{\mathrm{b}}, K_{t \mathrm{~b}}, K_{t \mathrm{p}}$ and $K_{t \mathrm{r}}$ and the data from which these constants were obtained. A value for $K_{t q}$ cannot be derived since it is not necessary to define $K_{l \mathrm{q}}$ to express the complete rate equation in terms of kinetic constants. The numerical values obtained by different methods for $K_{t \mathrm{p}}$ and $\boldsymbol{K}_{t \mathrm{r}}$ are sufficiently close to provide supporting evidence for the mechanism proposed.

Comparison of data for the benzylamine oxidases from beef and pig plasma

Oi et al. (1970) carried out a steady-state kinetic analysis of beef plasma benzylamine oxidase. Both the pig and beef enzymes show a family of parallel lines when double-reciprocal plots are made from the initial-velocity results, thus indicating that the two enzymes act through a Ping Pong mechanism.

Table 5. Predicted and observed product-inhibition patterns

For details see the text.

Predicted inhibition

Fixed substrate

\begin{tabular}{|c|c|c|c|}
\hline \multirow{2}{*}{$\begin{array}{l}\text { Variable } \\
\text { substrate }\end{array}$} & \multirow[b]{2}{*}{ Product } & \\
\hline & & $\mathrm{O}_{2}$ non-saturating & $\mathrm{O}_{2}$ saturating \\
\hline \multirow[t]{2}{*}{ Benzylamine } & $\begin{array}{l}\mathrm{NH}_{3} \\
\mathrm{H}_{2} \mathrm{O}_{2} \\
\text { Benzaldehyde }\end{array}$ & $\begin{array}{l}\text { Non-competitive } \\
\text { Uncompetitive } \\
\text { Competitive }\end{array}$ & $\begin{array}{l}\text { None } \\
\text { Uncompetitive } \\
\text { Competitive }\end{array}$ \\
\hline & & $\begin{array}{c}\text { Benzylamine } \\
\text { non-saturating }\end{array}$ & $\begin{array}{l}\text { Benzylamine } \\
\text { saturating }\end{array}$ \\
\hline \multirow[t]{2}{*}{$\mathrm{O}_{2}$} & $\begin{array}{l}\mathrm{NH}_{3} \\
\mathrm{H}_{2} \mathrm{O}_{2}\end{array}$ & $\begin{array}{l}\text { Competitive } \\
\text { Non-competitive }\end{array}$ & $\begin{array}{l}\text { Competitive } \\
\text { Non- } \\
\text { competitive }\end{array}$ \\
\hline & Benzaldehyde & Uncompetitive & None \\
\hline
\end{tabular}

Observed inhibition

Fixed substrate

\begin{tabular}{|c|c|}
\hline $\mathrm{O}_{2}$ non-saturating & $\mathrm{O}_{2}$ saturating \\
\hline $\begin{array}{l}\text { Non-competitive } \\
\text { Uncompetitive } \\
\text { Competitive }\end{array}$ & $\begin{array}{l}\stackrel{*}{*} \\
\text { Uncompetitive } \\
\text { Competitive }\end{array}$ \\
\hline $\begin{array}{c}\text { Benzylamine } \\
\text { non-saturating }\end{array}$ & $\begin{array}{l}\text { Benzylamine } \\
\text { saturating }\end{array}$ \\
\hline Competitive & $*$ \\
\hline Non-competitive & $\begin{array}{l}\text { Non- } \\
\text { competitive }\end{array}$ \\
\hline Uncompetitive & None \\
\hline
\end{tabular}

Table 6. Values for derived kinetic constants

For details see the text.

Kinetic constants

Numerical value

$\begin{array}{ll}K_{\mathrm{a}} & 5.0 \times 10^{-4} \\ K_{\mathrm{b}} & 1.8 \times 10^{-4} \\ K_{t \mathrm{~b}} & 1.3 \times 10^{-4} \\ K_{i \mathrm{p}} & 1.8 \\ & 0.67 \\ K_{i \mathrm{r}} & 1.4 \times 10^{-4} \\ & 0.9 \times 10^{-4}\end{array}$

Results used for derivation

Initial-velocity studies

Initial-velocity studies

$\mathrm{H}_{2} \mathrm{O}_{2}$ against $\mathrm{O}_{2}$ when benzylamine is non-saturating

$\mathrm{NH}_{3}$ against benzylamine when $\mathrm{O}_{2}$ is non-saturating

$\mathrm{NH}_{3}$ against $\mathrm{O}_{2}$ when benzylamine is non-saturating

Benzaldehyde against benzylamine when $\mathrm{O}_{2}$ is non-saturating

Benzaldehyde against $\mathrm{O}_{2}$ when benzylamine is non-saturating 
For the beef enzyme, the product-inhibition results suggest that benzaldehyde is the first product to be released; this is supported by the finding that approximately $1 \mathrm{~mol}$ of benzaldehyde/mol of enzyme is liberated anaerobically (Reed \& Swindell, 1969; Oi et al., 1970). The mechanism proposed by Oi et al. (1970) for the beef enzyme requires random order of $\mathrm{H}_{2} \mathrm{O}_{2}$ and $\mathrm{NH}_{3}$ release following $\mathrm{O}_{2}$ addition. To

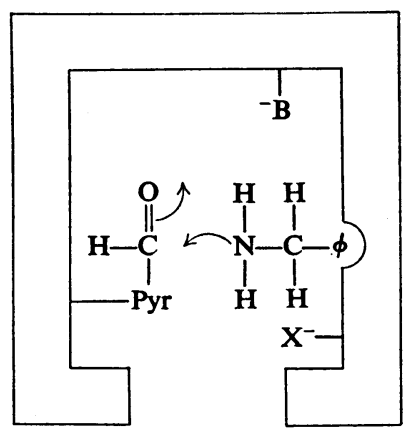

(I)

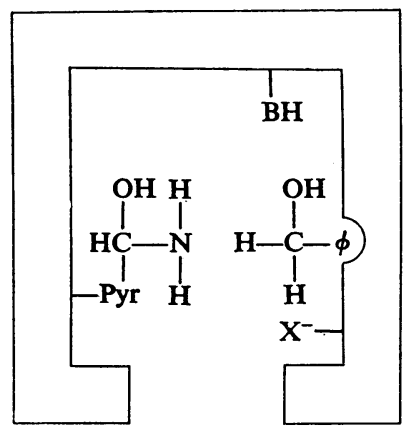

(V)
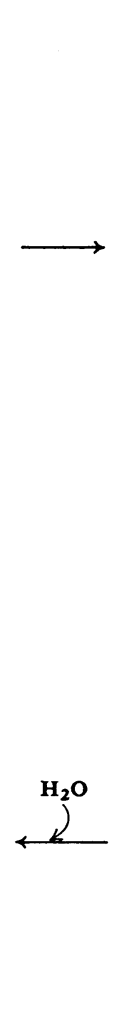

$\downarrow \mathrm{NH}_{3}$

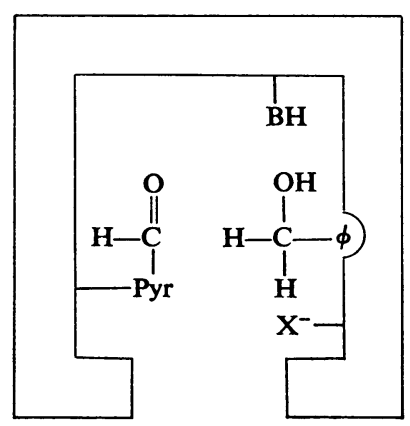

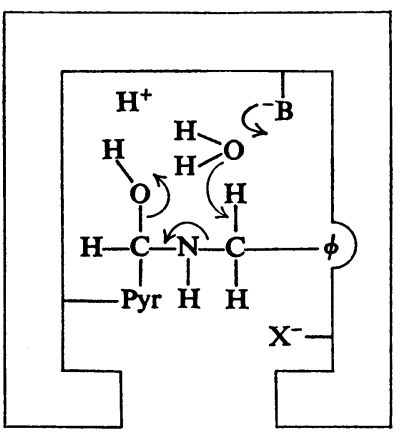

(II)

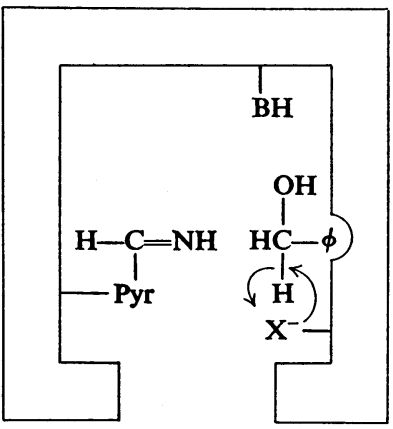

(IV)

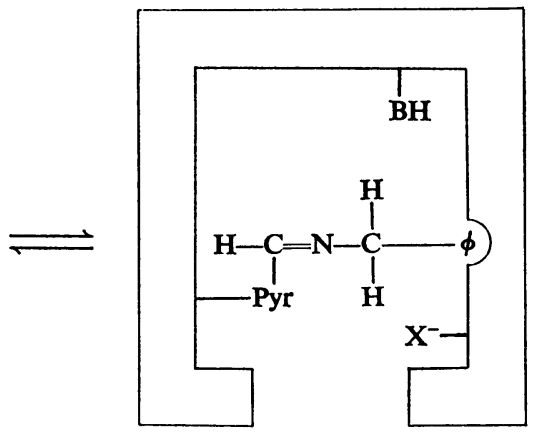

(III)

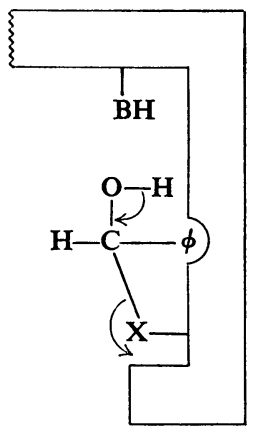

(VII)
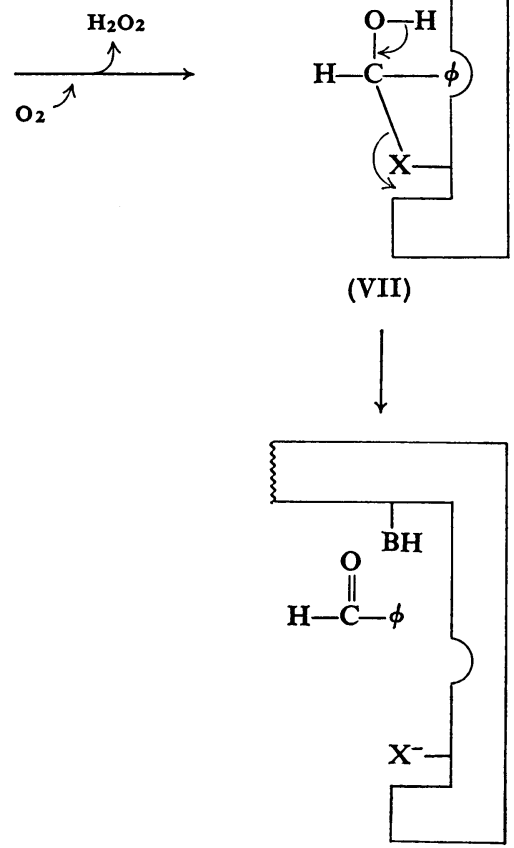

(VIII)

Scheme 1. Postulated chemical mechanism for pig plasma benzylamine oxidase Pyridoxal phosphate is abbreviated as PyrCHO. 
explain the observed non-competitive inhibition of $\mathrm{O}_{2}$ by benzaldehyde, a further isomerization of the enzyme has to be included in the mechanism.

The kinetic results presented in the present paper suggest that for the pig plasma enzyme, $\mathrm{NH}_{3}$ is the first product to be released after benzylamine binding. $\mathrm{O}_{2}$ is next bound and ordered release of $\mathrm{H}_{2} \mathrm{O}_{2}$, then benzaldehyde follows. The detection of $\mathrm{NH}_{3}$, but not benzaldehyde, under highly anaerobic conditions supports this order. A tentative chemical mechanism consistent with the kinetic and anaerobic product evidence, together with the ability of benzyl alcohol to act as a substrate, can be proposed (Scheme 1). Features of this mechanism are as follows:

(i) Benzylamine is bound at a hydrophobic site.

(ii) Attack by the lone-pair electrons of the amine on the carbonyl grouping of bound pyridoxal occurs giving the carbinolamine (II).

(iii,a). The $\mathrm{C}-\mathrm{N}$ bond of benzylamine is ruptured. An enzyme-bound nucleophile $\left(\mathrm{B}^{-}\right)$is suggested to assist this novel reaction which results in a pyridoxine as one fragment and enzyme-bound benzyl alcohol as the other (compound IV).

(iii,b) Intermediate (II) could be converted into the Schiff base (III) by a reaction not on the catalytic pathway. The formation of a Schiff base between substrate and enzyme has been reported (Buffoni, 1966).

(iv, a) Intermediate (IV) under anaerobic conditions is converted into compound (VI) with release of $\mathrm{NH}_{3}$. The pyridoxal phosphate regenerated in complex (VI) could perhaps bind a further molecule of benzylamine, converting it into a carbinolamine. This would be incapable of further reaction owing to the proximity of the bound benzyl alcohol. The observed bleaching by benzylamine of pyridoxal in the enzyme (Buffoni \& Blaschko, 1964) could thereby be rationalized.

(iv, b) Intermediate (IV) in the presence of $\mathrm{O}_{2}$ loses a hydride ion to yield $\mathrm{H}_{2} \mathrm{O}_{2}$. A nucleophilic grouping on the enzyme $\left(\mathrm{X}^{-}\right)$, for example persulphide (Edmonsen et al., 1972) and/or the cupric sites present in the enzyme, might participate in this step.

(v) Benzaldehyde is released from the enzyme.

The kinetic results for the beef and pig plasma enzymes would suggest different catalytic mechanisms. This is perhaps not surprising when one also considers the differences in substrate specificity (Yamada \& Yasunobu, 1962; Buffoni, 1966), dependence on ionic strength (Yamada \& Yasunobu, 1962) and on pH (Yasunobu \& Yamada, 1962) for the two enzymes. However, the difference might be experimental. Oi et al. (1970), in their studies on the ox plasma enzyme, did not observe any changes in the product-inhibition pattern from non-saturating to saturating conditions. This could, in our opinion, be due to their failure to achieve completely saturating fixed substrate concentrations.
The detection of benzaldehyde under anaerobic conditions with the ox plasma enzyme (Reed \& Swindell, 1969; Oi et al., 1970) is also subject to criticism. Neither group gave a value for the residual $\mathrm{O}_{2}$ in the $\mathrm{N}_{2}$ used. Moreover, the technique adopted by these authors of flowing $\mathrm{O}_{2}$-free $\mathrm{N}_{2}$ over a solution of the enzyme is less likely to produce truly anaerobic conditions than the technique used in the present investigation. Finally the enzyme concentrations used in their tests were too low to yield unambiguous results.

The evidence accumulated for the overall mechanism of the pig plasma enzyme is essentially consistent. For the ox plasma enzyme, more careful kinetic studies and assays for anaerobic production of benzaldehyde and $\mathrm{NH}_{3}$ are necessary. When these results are available, a conclusion may be drawn on whether the two enzymes function by different mechanisms.

We gratefully acknowledge discussions with Professor F. Buffoni, Professor W. W. Cleland and Dr. D. G. Herries. We thank Dr. L. Hart for computing the kinetic data and Mr. S. C. Charlton for developing part of the improved enzyme-purification procedure. This investigation was supported by Medical Research Council grants G 967/272/B and G 969/435/B.

\section{References}

Blaschko, H. \& Buffoni, F. (1965) Proc. Roy. Soc. Ser. B 163,45

Blaschko, H., Friedman, P. J., Hawes, R. \& Nillsson, K. (1959) J. Physiol. (London) 145, 384

Buffoni, F. (1966) Proc. Int. Symp. Chem. Biol. Aspects Pyridoxal Catal. 2nd. 363

Buffoni, F. \& Blaschko, H. (1964) Proc. Roy. Soc. Ser. B 161,153

Buffoni, F., Della Corte, L. \& Knowles, P. F. (1968) Biochem. J. 106, 575

Carothers, W. H., Bickford, C. F. \& Hurwitz, G. J. (1927) J. Amer. Chem. Soc. 49, 2908

Cleland, W. W. (1963a) Biochim. Biophys. Acta 67, 104

Cleland, W. W. (1963b) Biochim. Biophys. Acta 67, 188

Cleland, W. W. (1967) Annu. Rev. Biochem. 36, 77

Cleland, W. W. (1970) Enzymes, 3rd. edn., 2, 1

Curzon, G. (1966) Biochem. J. 100, 295

Dearden, J. C. \& Forbes, W. F. (1958) Can. J. Chem. 36, 1362

Edmonsen, D., Massey, V., Palmer, G., Beacham, L. M. \& Elion, G. B. (1972) J. Biol. Chem. 247, 1597

Estabrook, R. W. (1967) Methods Enzymol. 10, 41

Hill, J. M. (1967) Biochem. J. 104, 1048

Kolthoff, I. M. \& Sandell, E. B. (1952) Textbook of Quantitative Inorganic Analysis, 3rd. edn., p. 574, MacMillan Publishing Co., New York

Levitzki, A. (1970) Anal. Biochem. 33, 335

Mann, P. J. G. (1955) Biochem. J. 59, 609

Mann, P. J. G. (1961) Biochem. J. 79, 623

McEwan, C. M. (1965) J. Biol. Chem. 240, 2011

Meister, A. \& Wellner, D. (1963) Enzymes, 2nd. edn., 7, 609

Vol. 130 
Mondovi, B., Rotilio, G., Finazzi-Agro, A. \& SciosciaSantoro, A. (1964) Biochem. J. 91, 408

Mondovi, B., Rotilio, G., Costa, M. T., Finazzi-Agro, A., Chiancone, E., Hansen, R. E. \& Beinert, H. (1967) J. Biol. Chem. 242, 1160

Oi, S., Inamasu, M. \& Yasunobu, K. T. (1970) Biochemistry 9, 3378

Reed, D. J. \& Swindell, R. (1969) Fed. Proc. Fed. Amer. Soc. Exp. Biol. 28, 891

Swann, J. C. \& Bray, R. C. (1972) Eur.J. Biochem. 26, 407

Sweetser, P. B. (1967) Anal. Chem. 39, 979

Tabor, C. W., Tabor, H. \& Rosenthal, S. M. (1954) J. Biol. Chem. 208, 654

Taylor, C. (1971) Ph.D. Thesis, University of Leeds
Tiselius, A., Hjerten, S. \& Levin, O. (1956) Arch. Biochem. Biophys. 65, 132

Warburg, O. \& Christian, W. (1941) Biochem. Z. 310, 384

Wilkinson, G. N. (1961) Biochem. J. 80, 324

Yamada, H. \& Yasunobu, K. T. (1962) J. Biol. Chem. 237, 1511

Yamada, H. \& Yasunobu, K. T. (1963) J. Biol. Chem. 238, 2669

Yamada, H., Yasunobu, K. T., Yamano, T. \& Mason, H. S. (1963) Nature (London) 198, 1092

Yamada, H., Adachi, O. \& Yamano, T. (1969) Biochim. Biophys. Acta 194, 751

Yasunobu, K. T. \& Yamada, H. (1962) Proc. Symp. Chem. Biol. Aspects Pyridoxal Catal. 453 